\title{
Camless hydraulic valve timing system in combustion engines
}

\begin{abstract}
The paper discusses the control of the operation of combustion engines through a camless electro-hydraulic valve timing system aiming at a lower exhaust emission and increased overall efficiency. The paper presents an electro-hydraulic valve system and a mathematical model of the fluid flow. The model was simulated in Matlab-Simulink for different geometrical parameters of the hydraulic system and electric control parameters in order to obtain a required valve lift and timing in the Toyota Yaris gasoline 1.3 l engine. The paper presents the Simulink model and the results of calculation in Simulink. Additionally, a comparison of engine parameters with a standard cam valve system and those of the camless hydraulic valve timing system have been shown for different engine speeds obtained from the simulation in GT-Power software. The obtained results show a significant increase of the engine torque and efficiency at higher engine speeds for the considered camless system in the Toyota Yaris gasoline engine. The paper showsboth the advantages and disadvantages of the described valve system.
\end{abstract}

Key words: transport, combustion engines, valves, engine control

\section{Bezkrzywkowy hydrauliczny system sterowania zaworów w silnikach spalinowych}

\begin{abstract}
Artykut dotyczy sterowania praca silników spalinowych za pomoca bezkrzywkowego elektrohydraulicznego zaworowego rozrządu w celu uzyskania mniejszej emisji szkodliwych składników spalin i zwiększenia sprawności ogólnej. Elektrohydrauliczny zaworowy system zostat opracowany przez autorów niniejszego artykulu, a model matematyczny jest przdstawiony w tej publikacji. Caty model systemu zostat przeniesiony do programu Matlab-Simulink, gdzie byt następnie badany dla róznych parametrów geometrycznych układu hydraulicznego i różnych paremetrów sterowania elektrycznego w celu otrzymania pożąanego wzniosu i czasu otwarcia zaworów dla 4-suwowego silnika ZI YARIS 1,3 l. Artykut przedstawia model obliczeniowy w programie Simulink oraz wyniki obliczeń przeprowadzone w tym programie. Dodatkowo w publikacji przedstawiono parametry pracy silnika ze standardowym krzywkowym układem sterowania zaworami i bezkrzywkowym systemem dla różnych prędkości obrotowych otrzymane z symulacji przeprowadzonych $w$ programie GT-Power. Wyniki badań symulacyjnych wykazuja znaczacy wzrost momentu obrotowego $i$ sprawności ogólnej silnika Yaris przy bezkrzywkowym systemie sterowania zaworami. Wykazano zalety $i$ wady rozpatrywanego systemu zaworowego.

Słowa kluczowe: transport, silniki spalinowe, zawory, sterowanie
\end{abstract}

\section{Introduction}

Recently the engine timing system has gone through a substantial development in internal combustion engines. The engine designers are more and more limited by exhaust emission requirements and at the same time higher engine parameters are required. The applied timing systems in four-stroke engines have many limitations. The application of camshafts, pushers, valve levers, rods, springs, poppet valves and other elements limits the actual valve lift, impacts the velocity and acceleration of the moving parts and thus the inertia forces. Valves driven by mechanical system open and close according to a cam profile, which is convex for the contact of the cam with the pusher. This fact causes that the valves can be opened only in the limit of about $240 \mathrm{deg}$ CA. Longer or shorter opening of the valve is possible only by applying of special system with a variable cam profile or by using a camshaft with two or three cams for each valve. Such solutions were applied in the Toyota engines in the VVTL system or in the Honda engines, where the VTEC system was utilized. The engine works at different loads and different speeds. Therefore, the demand for air changes, particularly in spark ignition engines, where the total excess

\section{Wstęp}

W ostatnim czasie układ rozrządu silnika jest jednym z najbardziej rozwijanych systemów silnika spalinowego. $Z$ jednej strony konstruktorzy silników są coraz bardziej ograniczani przez wymagania dotyczące norm emisji spalin, z drugiej zaś - zwiększają ich parametry. Systemy rozrządu stosowane do tej pory w silnikach czterosuwowych mają wiele wad. Składając się z wałka rozrządu, popychaczy, dźwigni zaworowych, sprężyn, zaworów grzybkowych oraz innych elementów ograniczających wznios zaworu, wpływają na prędkość oraz przyspieszenie ruchomych części, a zatem i na siły bezwładności. Zawory o napędzie mechanicznym otwierają i zamykają się w zależności od profilu krzywki, który zapewnia prawidłową pracę z popychaczem. Kinematyka układu krzywkowego powoduje, że zawory mogą być otwierane przez ok. 240 stopni obrotu wału korbowego. Dłuższy bądź krótszy czas otwarcia mogą zapewnić specjalne systemy zmieniające charakter wzniosu zaworu. Tego typu rozwiązania stosuje firma Toyota $\mathrm{w}$ swoich silnikach z systemem VVTL oraz Honda w silnikach z systemem VTEC. Silnik pracuje z różnymi obciążeniami oraz prędkościami obrotowymi i z tego względu zmienne jest 
air coefficient approximates 1 . The mentioned Toyota and Honda solutions are an innovative technique called variable valve timing. Modern engines are characterized by a higher overall efficiency in the whole range of engine speeds, which can be done through changing of the valve time-area. Conventional design of the cam profile leads to a lower value of this parameter. By applying electronic control it is possible to control the valve mechanical systems in order to obtain better engine parameters

\section{Goal and scope}

Mechanical systems give a limited interference in the range of the valve lift and its profile. Automotive research centers conduct very intense work on solutions giving a full control of the engine valve timing system. A promising solution is the electronically controlled hydraulic system. The goal of this work is to present the solution developed at Cracow University of Technology. The authors developed a hydraulic drive system of poppet valves, where the liquid flowing in the servomotors is controlled by an electronic unit. On the market there are only a few quasi hydraulic solutions for such systems. In comparison to the electromagnetic valve unit this solution has smaller dimensions, is quieter and does not require so much electrical energy. The scope of this work contained: the design of the hydraulic valve system, developing of a precise mathematical model of the physical processes occurring in the system, simulation of the work of the valve hydraulic unit in Matlab-Simulink environment [7], optimization of the geometrical parameters and as the last step, a simulation of the operation of a four-stroke engine Toyota Yaris 1.31 in GT-Power for 3 valve timing systems in order to compare the power, fuel consumption and volumetric efficiency. Because of the limitations the paper presents a description of the new hydraulic system driven poppet valves, a description of the Simulink model with the results of the lift simulation and a comparison of the results of the engine parameters obtained from GT-Power simulation.

\section{Camless valve timing systems}

The course of the valve lift decides about the mass flow rate of the air or the exhaust gases and it is more important for the intake valve. The required valve lift and the course of

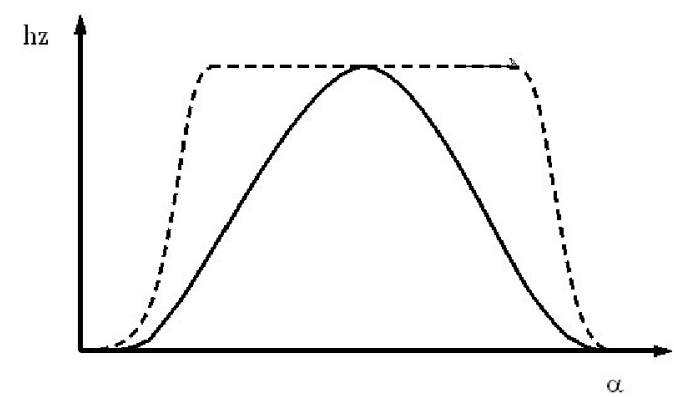

Fig. 1. Diagram of possible valve lift: continuous line - by cam, dashed line - required lift

Rys. 1. Wykres przebiegu wzniosu jako funkcja kąta obrotu watu korbowego: linia ciagła - napędzany krzywka, linia przerywana-pożadany przebieg jego zapotrzebowanie na powietrze, zwłaszcza dla silników o zapłonie iskrowym, gdzie współczynnik nadmiaru powietrza powinien być bliski jeden. Wspomniane innowacyjne rozwiązania Toyoty oraz Hondy określane są mianem zmiennych faz rozrządu. Współczesne silniki spalinowe powinny charakteryzować się wysokim współczynnikiem sprawności w całym zakresie prędkości obrotowej, co może być możliwe dzięki zmianie czasoprzekroju zaworów. Tradycyjny kształt krzywki zapewnia małe wartości wspomnianego parametru. Przy wykorzystaniu elektronicznie regulowanego systemu rozrządu istnieje możliwość sterowania zaworami w taki sposób, by uzyskać wysokie parametry robocze i ekonomiczne pracy silnika spalinowego.

\section{Cel i zakres}

Mechaniczne systemy powodują ograniczenia w zmianie charakteru oraz wysokości wzniosu zaworu. Motoryzacyjne ośrodki badawcze intensywnie pracują nad systemem rozrządu zaworów dającym pełną kontrolę pracy. Jednym z obiecujących rozwiązań jest hydrauliczny system sterowany elektronicznie. Celem niniejszej pracy jest przedstawienie rozwiązań opracowanych w Politechnice Krakowskiej dotyczących hydraulicznie napędzanego systemu sterowania zaworów, w którym ciecz przepływająca przez rozdzielacz hydrauliczny regulowana jest przez sterownik. Na rynku istnieje tylko kilka pseudorozwiązań hydraulicznych tego typu. W porównaniu z systemem napędzania zaworów realizowanym przez elektromagnesy takie rozwiązanie cechuje się mniejszymi wymiarami, cichszą pracą oraz nie wymaga dużej energii elektrycznej. Zakres prac podjętych w Politechnice Krakowskiej obejmował: zaprojektowanie zaworu hydraulicznego, opracowanie dokładnego modelu matematycznego procesów fizycznych zachodzących w systemie, symulację pracy hydraulicznego zaworu w Matlab-Simulink [7], optymalizację geometrycznych wymiarów części składowych systemu oraz w ostatniej kolejności symulację pracy czterosuwowego silnika Toyota Yaris 1.31 w programie GT-Power dla trzech układów rozrządu w celu porównania uzyskanej mocy, jednostkowego zużycia paliwa oraz objętościowego współczynnika napełnienia cylindra. Z uwagi na ograniczoną objętość artykułu przedstawiono tylko opis nowego hydraulicznego systemu sterowania zaworami, opis modelu Simulink z rezultatami symulacji oraz wyniki porównania parametrów różnych rozwiązań uzyskanych podczas symulacji w programie GT-Power.

\section{Bezkrzywkowy system sterowania zaworów}

Przebieg skoku zaworu decyduje o natężeniu przepływu powietrza lub spalin. Pożądany wznios zaworu oraz wznios uzyskany za pomocą typowej krzywki pokazano na rys.1. Bezkrzywkowy system ruchu zaworów umożliwia osiągnięcie większych wartości czasoprzekroju otwarcia zaworu (przerywana linia) i jest bardziej odpowiedni dla nowoczesnych silników spalinowych.

Jednym z pierwszych bezkrzywkowych układów rozrządu była propozycja oparta na elektromagnesach. To bardzo proste rozwiązanie zostało opracowane przez ośrodek badawczy firmy FEV. Nosi ono nazwę Electro-Mechanical 
the valve lift driven by a typical cam has been shown in Fig. 1. Camless valve systems enable an obtainment of higher values of the time-area (dashed line) and are more suitable for modern combustion engines.

One of the first camless solutions was the electromagnetic valve system. A very simple solution is the design developed by FEV an engine research company. The system is referred to as Electro-Mechanical Valve (EMV) [4] that enables an obtainment of a wide range of control of the engine timing system. Electromagnetic system consists of two electromagnets, a core joined with the valve stem and two springs. Three different alternatives of the drive operation of the EMV have been shown in Fig. 2: without feed, open valve and closed valve. The opening time of the valve $3 \mathrm{~ms}$, which corresponds to the engine speed of $6000 \mathrm{rpm}$. The main problem of such a solution is the heating of the coils, work noise and high electrical energy consumption (higher voltage).

A hydraulic valve system utilizes high pressure of the working medium. Some aspects of the operation of a hydraulically actuated valve train were presented by Zbierski and Smoczynski [11]. The valve is connected to the piston rod in the servomotor, which contains pressurized liquid. The working medium that can be a lubricant is transmitted from a pressure accumulator through a distributor directing the liquid to a required side of the piston. The principle of operation of the hydraulic valve drive has been shown in Fig. 3. These systems work under pressure from 8 to $50 \mathrm{MPa}$ and hence they do not need large dimensions of the piston rod and it is possible have a very short valve opening time of about 2 $\mathrm{ms}$. The work of such a system is more silent and the system provides better reliability, however the hydraulic valve system is much more complex and louder than the conventional cam valve system.

The flow of liquid is controlled by the slider in chamber fed by the high pressure of the pump. The liquid is moved to the piston rod side and acts on its bottom or topside depending on the position of the slider. Pneumatic system of the valve drive works analogically as the hydraulic one. Its work is based on low pressure of the gas (most frequently
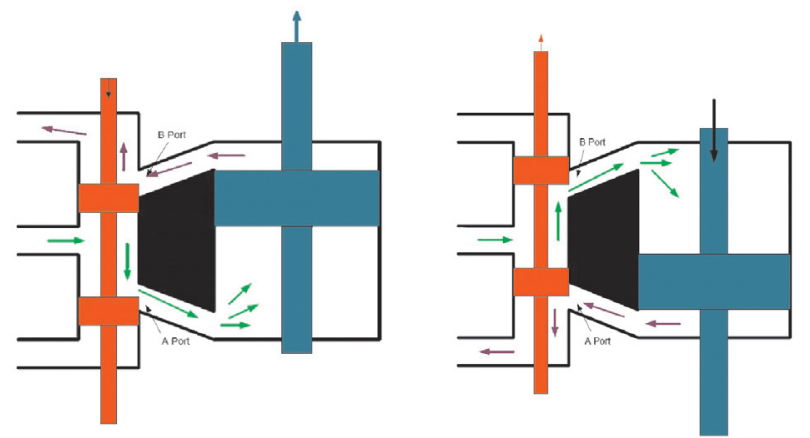

Fig. 3. Principle of operation of a hydraulic valve drive Rys. 3. Zasada działania napędu hydraulicznego zaworów
Valve (EMV) [4] i pozwala uzyskać szeroki zakres sterowania układu rozrządu silnika spalinowego. Rozwiązanie składa się z dwóch elektromagnesów, rdzenia, zaworu oraz dwóch sprężyn. Możliwe są trzy tryby pracy tego urządzenia pokazane na rys. $2: \mathrm{z}$ wyłączonym zasilaniem, otwarcie zaworu, zamknięcie zaworu. Czas otwarcia zaworu wynosi $3 \mathrm{~ms}$, co umożliwia uzyskanie prędkości obrotowej równej $6000 \mathrm{obr} / \mathrm{min}$ przez silnik spalinowy. Głównym problemem tego typu rozwiązania jest nadmierne grzanie się cewek elektromagnesu oraz duże zapotrzebowanie na energię elektryczną (wysokie napięcie).

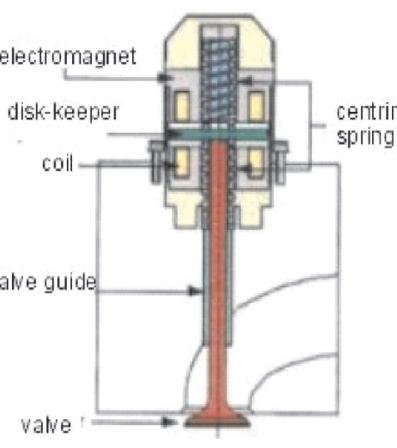

non-feeded

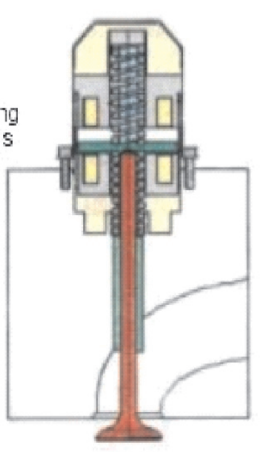

open

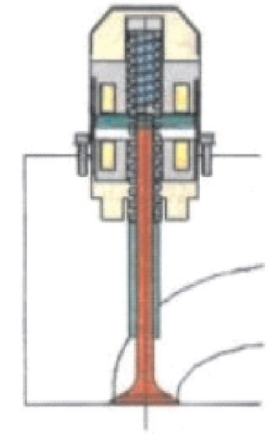

close
Fig. 2. Valve cases realized by the EMV system [4]

Rys. 2. Warianty trybów pracy systemu EMV [4]

Hydraulicznie napędzany system rozrządu wykorzystuje duże ciśnienie czynnika roboczego. Niektóre aspekty hydraulicznego napędu rozrządu zostały przedstawione przez Zbierskiego i Smoczyńskiego [11]. Zawór grzybkowy połączony jest z tłoczyskiem siłownika, na które działa ciecz pod ciśnieniem. Czynnik roboczy, jakim może być olej silnikowy, przekazywany jest ze zbiornika ciśnienia przez rozdzielacz hydrauliczny do odpowiedniej komory siłownika. Zasadę działania napędu hydraulicznego zaworów pokazano na rys.3. Ten system działa dla ciśnień z zakresu od 8 do $50 \mathrm{MPa}$ i dlatego można zastosować tłok o niewielkich wymiarach. Dzięki temu rozwiązaniu możliwe jest osiągnięcie czasu otwarcia równego $2 \mathrm{~ms}$. Praca tego systemu jest cichsza i bardziej niezawodna od rozwiązań opartych na elektromagnesach, jednak cechuje go większy stopień skomplikowania i głośniejsza praca niż w konwencjonalnym układzie rozrządu napędzanym przez krzywkę.

Przepływ cieczy kontrolowany jest przez suwak rozdzielacza, który kieruje ciśnienie wytworzone przez pompę do odpowiedniej komory siłownika. Różnica ciśnień pomiędzy komorami wywołana przez ciecz porusza tłoczysko w górę lub w dół, w zależności od ustawienia suwaka. Pneumatyczny system napędu zaworów jest analogiczny do hydraulicznego. Występują w nim zazwyczaj mniejsze ciśnienia gazu (najczęściej powietrza), co powoduje konieczność stosowania dużych średnic tłoczyska. Schemat układu pneumatycznego opracowany został w pracy magisterskiej Bradena [2] (rys. 4). System tego typu nie musi spełniać 
air), which forces the application of a bigger diameter of the piston rod. The diagram of the pneumatic valve system with the control unit described by Braden [2] in his master's thesis has been in Fig. 4. The unit does not require a high airtight seal and any possible leakage is not hazardous for environment.

\section{Solution of hydraulic valve system}

A mathematical model of the hydraulic valve system was developed that took into account the inertia forces, friction forces and hydrodynamic forces. The control of the motion of the piston rod takes place by moving of the distributor slider, which is caused by the electromagnets. Additional mathematical models are related to the liquid flow in the slider distributor and the flow between the distributor and servomotor. The diagram of the elaborated hydraulic valve system has been shown in Fig. 5 with the

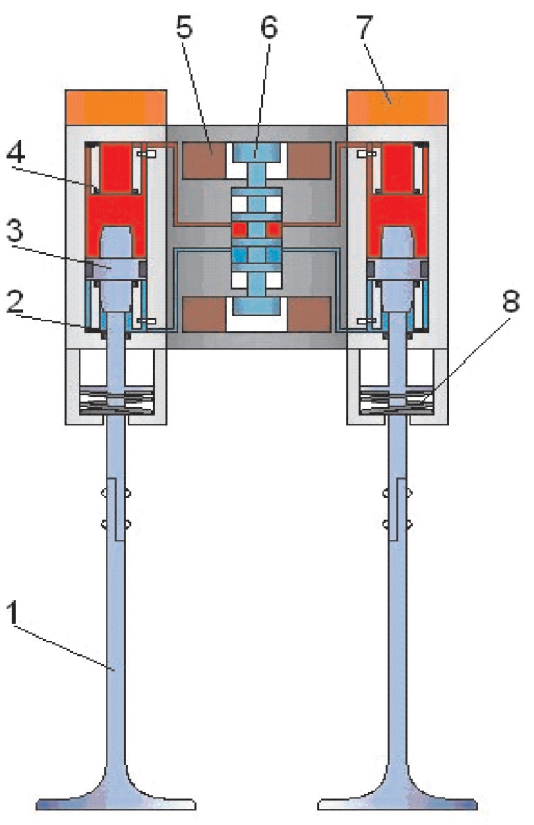

Fig. 5. The diagram of the unit consisting of a distributor, servomotor and position sensors: 1 - engine valve, 2 - chamber A, 3 - piston rod, 4 - chamber B, 5 - electromagnet, 6 - distributor slider, 7 - position sensor, 8 - protective spring

Rys. 5. Schemat zespotu rozdzielacz, sitowniki oraz czujniki położenia: 1 - zawór silnikowy, 2 - komora B, 3 - ttoczysko, 4-komora A, 5 - elektromagnes, 6 - suwak rozdzielacza, 7 - czujnik położenia, 8 - sprężyna zabezpieczająca

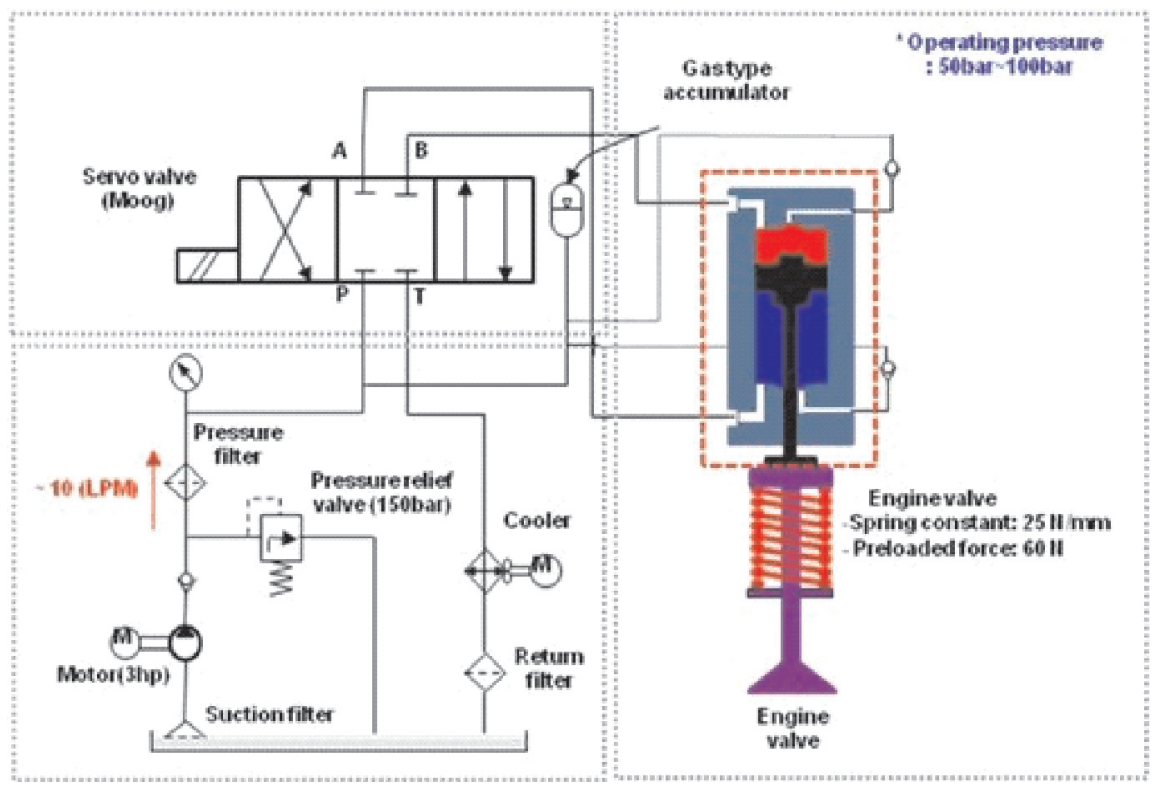

Fig. 4. Diagram of pneumatic system of valve drive [2] Rys. 4. Schemat pneumatycznego napędu zaworów [2]

warunku hermetycznej szczelności, a ewentualne wycieki nie szkodzą środowisku. specified parts.

The solution presented in Fig. 5 takes into account two valves (intake or exhaust) de-

\section{Rozwiązanie hydraulicznego układu zaworów}

Opracowany matematyczny model hydraulicznego systemu sterowania zaworów uwzględnia siły bezwładności, siły tarcia i siły hydrodynamiczne. Kontrola ruchu tłoczyska odbywa się przez ruch suwaka rozdzielacza, wywołany elektromagnesami. Schemat opracowanego hydraulicznego

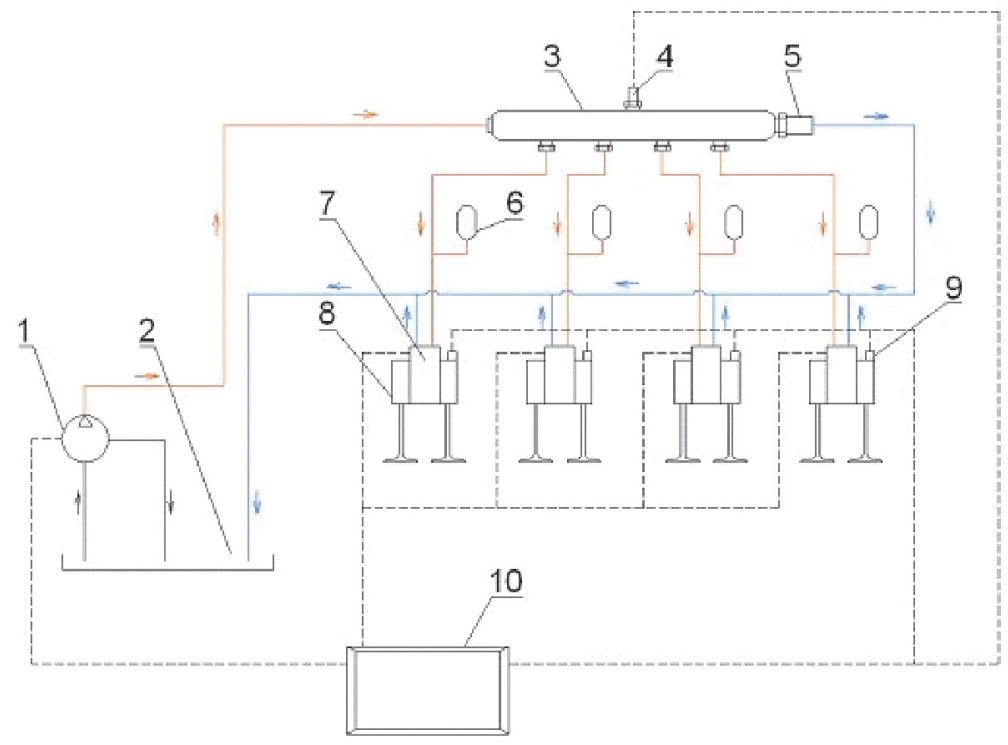

Fig. 6. Diagram of the engine timing system with the hydraulic drive: 1 - oil pump, 2 - oil bath, 3 - pressure accumulator, 4 - pressure gauge, 5 - safety-valve, 6 - individual pressure accumulator, 7 - slider controlled by an electromagnet, 8 - servomotor, 9 -piston-rod position sensor, $10-\mathrm{ECU}$

Rys. 6. Schemat układu rozrządu silnika spalinowego o napędzie hydraulicznym: 1 - pompa olejowa, 2 -zbiornik oleju, 3 -zasobnik ciśnienia, 4 - czujnik ciśnienia, 5 -zawór bezpieczeństwa, 6-indywidualny akumulator ciśnienia, 7-rozdzielacz suwakowy, 8-siłownik, 9-czujnik położenia tłoczyska, $10-E C U$ 
signed for the majority of modern engines. The kinematic and dynamic analyses require knowledge of the dimensions of the unit and mass of all the moving parts. The precise mathematical model of the hydraulic system will be the subject of the other publication.

The diagram of the timing system driven by hydraulic unit for a four cylinder engine has been shown in Fig. 6. The system is fitted with two pressure accumulators: the main one and an additional one for each valve unit.

\section{Simulation model of valve control}

Digitizing of the mathematical model of the developed hydraulic valve drive was carried out in Matlab/Simulink software [7]. Modeling and computing of the hydraulic systems was based on the operation of Dindorf [3] and Wolkow [11]. The computer model was created on the basis of the mathematical model taking into account all possible liquid flows and forces in a short time of the system operation. The computer modeling had some simplifications concerning the limitation of the number of the simulated elements. The computer models that simulated the valve motion under the influence of the pressure exerted on the piston rod of the servomotor, have a modular character of the structure. The model in Simulink shown in Fig. 7 is based on the mathematical equations describing physical phenomena and is divided into the following modules:

a) distributor - mechanical part,

b) distributor - flow part,

c) servomotor - mechanical part

d) servomotor - flow part,

e) additional modules.

Each module has a flow control or the control of the mechanical parameters and is a separate Simulink part. All modules solve differential equations of the system of motion of the mechanical part and include the elements of the flow parameters of the liquid.

For example, the flow part of the distributor and the mass flow rate are determined in the channels of the servomotors

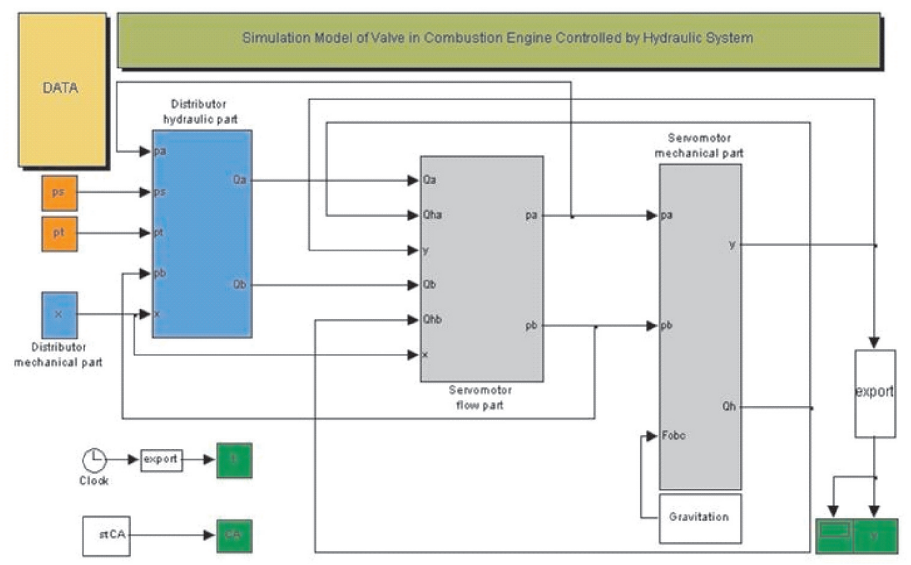

Fig. 7. The Diagram of the computation model of the electro-hydraulic valve drive in Matlab-Simulink program

Rys. 7. Schemat modelu matematycznego elektrohydraulicznego napędu zaworów wykonanego w programie Matlab-Simulink układu rozrządu pokazano na rys. 5 z uwzględnieniem części składowych.

Rozwiązanie przedstawione na rys. 5 zakłada sterowanie dwoma zaworami (dolotowymi lub wylotowymi). Analiza kinematyczna i dynamiczna wymaga przedstawienia wymiarów i mas wszystkich ruchomych części urządzenia. Dokładny model matematyczny będzie przedmiotem innych publikacji.

Schemat całego układu hydraulicznego systemu napędu zaworów dla czterocylindrowego silnika spalinowego przedstawiono na rys. 6. System ma dwa akumulatory ciśnienia: główny oraz dodatkowy dla każdego układu zaworów.

\section{Model symulacyjny sterowania zaworami}

Obliczenia numeryczne modelu matematycznego opracowanego napędu hydraulicznego zaworów przeprowadzono w programie Matlab-Simulink [7]. Model matematyczny opiera się na pracach Dindorfa [3] i Wołkowa [11]. Symulacja komputerowa bazująca na modelu matematycznym uwzględnia wszystkie możliwe przepływy cieczy oraz siły działające na układ. Posiada ona pewne uproszczenia wpływające na zmniejszenie potrzebnej mocy obliczeniowej komputera. Model komputerowy, który symuluje pracę siłownika hydraulicznego sterowanego rozdzielaczem ma charakter modułowy. Model w Simulinku pokazany na rys. 7 jest podzielony na następujące moduły:

a) rozdzielacz - część mechaniczna,

b) rozdzielacz - część przepływowa,

c) siłownik - część mechaniczna,

d) siłownik - część przepływowa,

e) pozostałe moduły.

Każdy moduł składa się z parametrów określających przepływ cieczy lub ruch elementów wykonawczych i jest oddzielną częścią w programie Simulink. Moduły rozwiązują równania różniczkowe związane $\mathrm{z}$ ruchem mechanicznych części wywołanym przez przepływającą ciecz. Na przykład w części przepływowej rozdzielacza wyznaczane są natężenia przepływów przez kanały rozdzielacza z sygnałów wejściowych, którymi są: przemieszczenie suwaka, ciśnienie zasilania, ciśnienie w zbiorniku, ciśnienie panujące w komorze $\mathrm{A}$, ciśnienie panujące $\mathrm{w}$ komorze B. Sygnałami wyjściowymi są: natężenie przepływu w kanale komory A siłownika, natężenie przepływu w kanale komory B siłownika.

Podczas symulacji wyznacza się wiele charakterystyk, na przykład: wznios zaworu, prędkość i przyspieszenie tłoczyska, siły bezwładności jako funkcja mas ruchomych części w zależności od czasu. Ruch zaworu zależy od przemieszczenia suwaka rozdzielacza. Na rysunku 8 przedstawiono ruch suwaka w funkcji czasu w zależności od czasu przesterowania rozdzielacza tr.

Przy mniejszych czasach przesterowania ruch suwaka jest krótszy dla tego samego ciśnienia równego $15 \mathrm{MPa}$. Ten parametr może być wykorzystany do sterowania czasoprzekroju zaworu. Jednym z przykładów przeprowadzonych badań było określenie zależności wzniosu zaworu w 
and input signals are as follows: slider movement, feeding pressure, operating pressure, chamber pressure and pressure in chambers $\mathrm{A}$ and $\mathrm{B}$. The output signals are as follows: mass flow rate in the channel of chambers $\mathrm{A}$ and $\mathrm{B}$ of the servomotor.

The output signals are: mass flow rate in the channel of chambers A and B of the servomotor. During the simulation several characteristics were determined such as: valve lift, velocity and acceleration, inertia forces as a function of mass of parts taking part in the motion as well as time. The valve motion depends on the slider movement. Figure 8 presents the course of the slider movement in time at different re-adjusting time tr.

At lower re-adjusting time, the slider movement is shorter at the same feeding pressure of $15 \mathrm{MPa}$. This parameter can be useful for the control of the valve time-area value. One example of the calculation is a determination of the valve lift as a time function at dif-

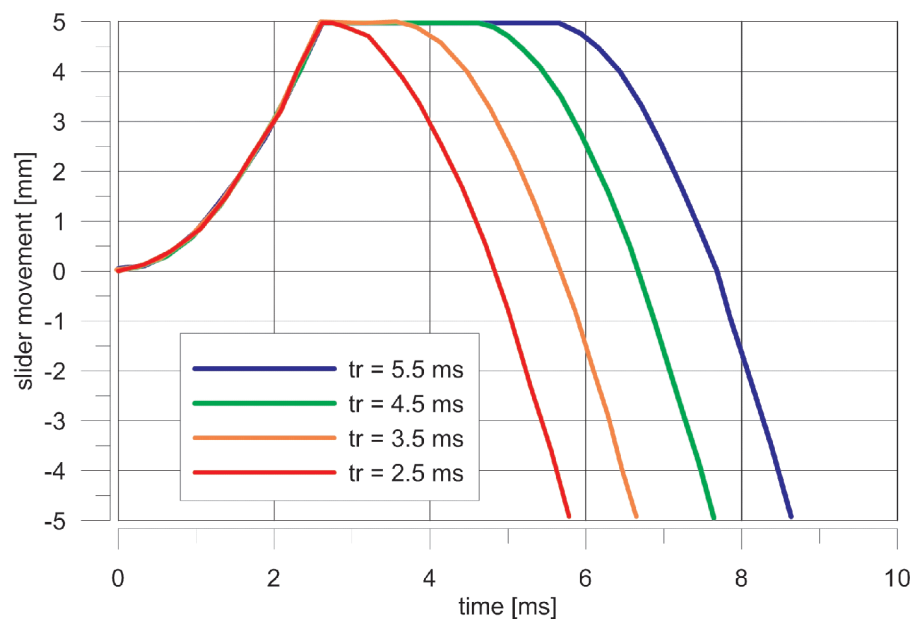

Fig. 8. The course of the slider movement at different re-adjusting time tr (2.5-5.5 ms) and liquid pressure $15 \mathrm{MPa}$

Rys. 8. Przebieg ruchu suwaka rozdzielacza w zależności od różnych czasów przesterowania tr (2,5-5,5 ms) i przy ciśnieniu cieczy $15 \mathrm{MPa}$

ferent liquid pressures as has been shown in Fig. 9. Higher pressure enables to obtain shorter time of the valve opening. The constant values are piston diameter $10 \mathrm{~mm}$ and the readjusting time amounting to $3.5 \mathrm{~ms}$. The change of pressure of the working fluid besides the re-adjusting time is the main control parameter of the valve motion.

\section{Simulation of engine parameters}

Determination of the lift parameters in the Simulink software for the assumed geometry of the hydraulic valve drive enables a simulation of the work of the designed solution in a computer model of a selected internal combustion engine. The GT-Power software was used for this purpose. It is commonly used in the automotive sector. In the software the main work parameters such as power, torque, specific fuel consumption and volumetric ratio were compared for

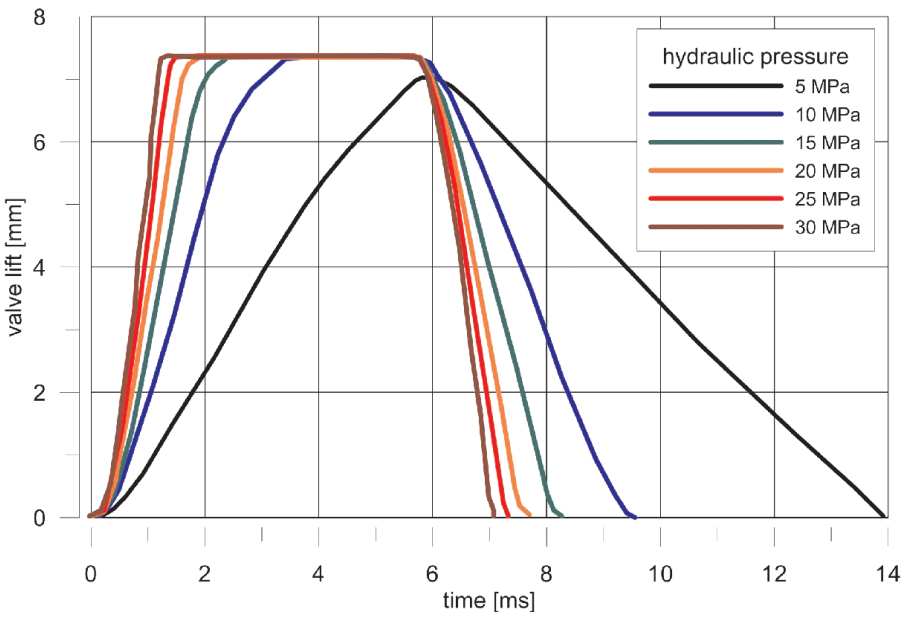

Fig. 9. The variation of the valve lift in time at different hydraulic pressures

Rys. 9. Zmiana skoku zaworów w czasie przy różnych ciśnieniach cieczy

funkcji czasu przy różnych ciśnieniach czynnika roboczego (rys. 9). Większe wartości ciśnienia powodują skrócenie czasu otwarcia zaworu. Parametrami stałymi w tych obliczeniach była średnica tłoczyska wynosząca $10 \mathrm{~mm}$ oraz czas przesterowania osiągający wartość 3,5 ms. Zmiany ciśnienia czynnika roboczego, oprócz czasu przesterowania rozdzielacza, są głównym parametrem sterowania ruchem zaworu.

\section{Symulacja parametrów pracy silnika}

Określenie parametrów wzniosu zaworu w programie Simulink dla określonych wymiarów geometrycznych zaworu hydraulicznego umożliwia symulację pracy zaprojektowanego rozwiązania w komputerowym modelu wybranego silnika spalinowego. W tym celu wykorzystany został program GT-Power, który jest powszechnie stosowany w branży motoryzacyjnej. Zostały w nim określone główne parametry pracy silnika, takie jak moc, moment obrotowy, jednostkowe zużycie paliwa oraz objętościowy współczynnik napełniania cylindra dla trzech wybranych układów rozrządu. Program umożliwia stworzenie modułowej struktury elementów przepływowych silnika. Obiektem symulacji został czterosuwowy silnik pochodzący z Toyoty Yaris. Główne parametry techniczne tego silnika przedstawiono w tab. 1. Schemat obliczeniowego modelu silnika stworzonego $\mathrm{w}$ programie GT-Power przedstawiono na rys. 10, gdzie inlet i outflow z odpowiednimi numerami oznaczają zawory

Table 1. The technical data of the tested engine

Tabela 1. Parametry techniczne testowanego silnika

\begin{tabular}{|l|c|}
\hline Cylinder number/liczba cylindrów & 4 \\
\hline Fueling system/system paliwowy & MPI \\
\hline Bore/Stroke/średnica cylindra/skok tloka & $75 / 73.5 \mathrm{~mm}$ \\
\hline Compression ratio/stopień sprężania & 10.3 \\
\hline $\begin{array}{l}\text { Valve number per cylinder/liczba zaworów } \\
\text { przypadająca na cylinder }\end{array}$ & 4 \\
\hline Intake valve diameter/średnica zaworu dolotowego & $23 \mathrm{~mm}$ \\
\hline Exhaust valve diameter/średnica zaworu wylotowego & $20 \mathrm{~mm}$ \\
\hline
\end{tabular}




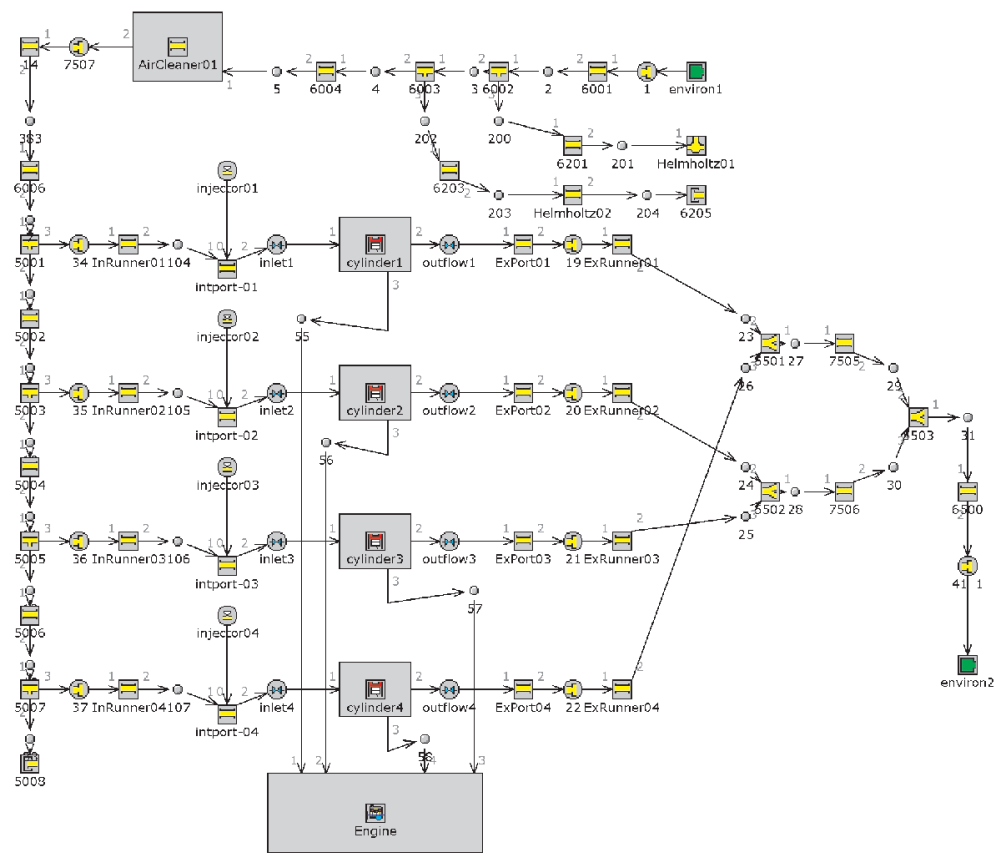

Fig. 10. The diagram of the computation model of a gasoline 4-stroke engine Yaris 1.31 in the GT-Power software

Rys. 10. Schemat modelu obliczeniowego silnika Yaris 1,3 l, 4-swuwowego ZI w programie GT-Power

three selected timing systems. The software enables a creation of a module structure of all the engine flow units. The four-stroke gasoline engine Toyota Yaris was the simulation object. The main technical data have been given in Table 1 . The diagram of the calculation model of the engine in GTPower has been presented in Fig. 10, where the intake and exhaust (numbered) indicate intake and exhaust valves. The valve lifts for the three cases were entered as data into the software in the form of tables. For the hydraulic valve system they were obtained from the simulation in Simulink.

The valve control by the hydraulic system can reach an assumed lift in an assumed time. A trapezoid course of the valve lift for this case with the hydraulic pressure $20 \mathrm{MPa}$ was assumed in this case. For all the cases the same crankshaft angle rotation of the poppet valve opening was assumed. An increase in the engine speed course of the valve lift yields a change of course of valve lift.

It was assumed that the gasoline mixture in the engine is homogenous with the excess air coefficient equal to 1 (stoichiometric mixture). On the basis of the computational model the courses of the pressure, temperature in the whole engine system and the main engine operating parameters were determined.

\section{Calculation results}

The preliminary computer analysis shows a possibility of applying of a hydraulic valve drive system to obtain a significant improvement of the engine parameters particularly at higher engine speeds. Through increasing of the flow area at the intake valve seat during dolotowe i wylotowe. Wzniosy zaworów dla wszystkich trzech przypadków zostały wprowadzone do programu w formie tablic. Dla hydraulicznego systemu zaworów otrzymano je z symulacji w programie Simulink.

Zawór kontrolowany przez hydrauliczny system może osiągnąć określony wznios w określonym czasie. Trapezowa charakterystyka ruchu zaworu została osiągnięta przy założeniu ciśnienia hydraulicznego równego $20 \mathrm{MPa}$. We wszystkich przypadkach przyjęto ten sam kąt otwarcia zaworów. Zwiększenie prędkości obrotowej powoduje zmianę charakterystyki wzniosu zaworu.

Symulacja dla trzech przypadków była prowadzona dla współczynnika nadmiaru powietrza równego jeden (stechiometryczna mieszanka). Na podstawie modelu komputerowego określono ciśnienia i temperatury w silniku oraz jego główne parametry.

\section{Wyniki obliczeń}

Wstępna analiza wyników symulacji komputerowej wskazuje na wzrost głównych parametrów pracy silnika spalinowego, szczególnie przy większych prędkościach obrotowych z wykorzystaniem hydraulicznie napędzanego systemu rozrządu. Przez zwiększenie czasu otwarcia zaworu, większa ilość mieszanki może wpłynąć do cylindra. Objętościowy współczynnik napełnienia cylindra jest większy niż w konwencjonalnym układzie rozrządu. Obliczenia przeprowadzone były przy maksymalnie otwartej przepustnicy, w zakresie prędkości obrotowych od 1000 do 7000 obr/min. Przy większych prędkościach obrotowych moc silnika jest również większa w porównaniu z układem rozrządu napędzanym krzywką. Na rysunku 11 pokazano

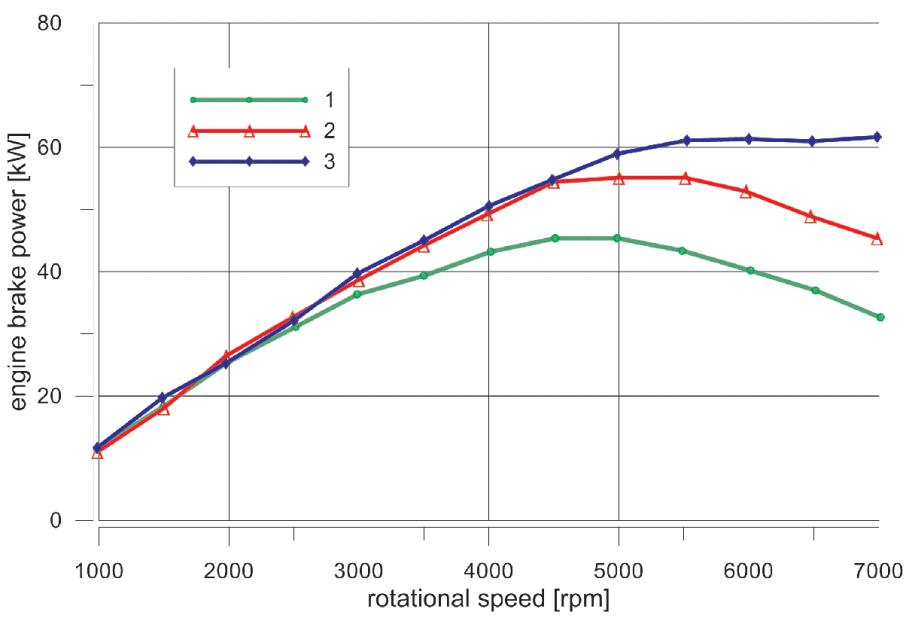

Fig. 11. The calculated engine power for different types of valve drive systems: 1 - valve driven by a camshaft, 2 - intake valves with a hydraulic drive, 3 - intake and exhaust valves driven by a hydraulic system

Rys. 11. Obliczona moc silnika dla różnych układów rozrządu: 1-zawory napędzane krzywka, 2-zawory dolotowe napędzane hydraulicznie, 3 -zawory dolotowe $i$ wylotowe napędzane hydraulicznie 


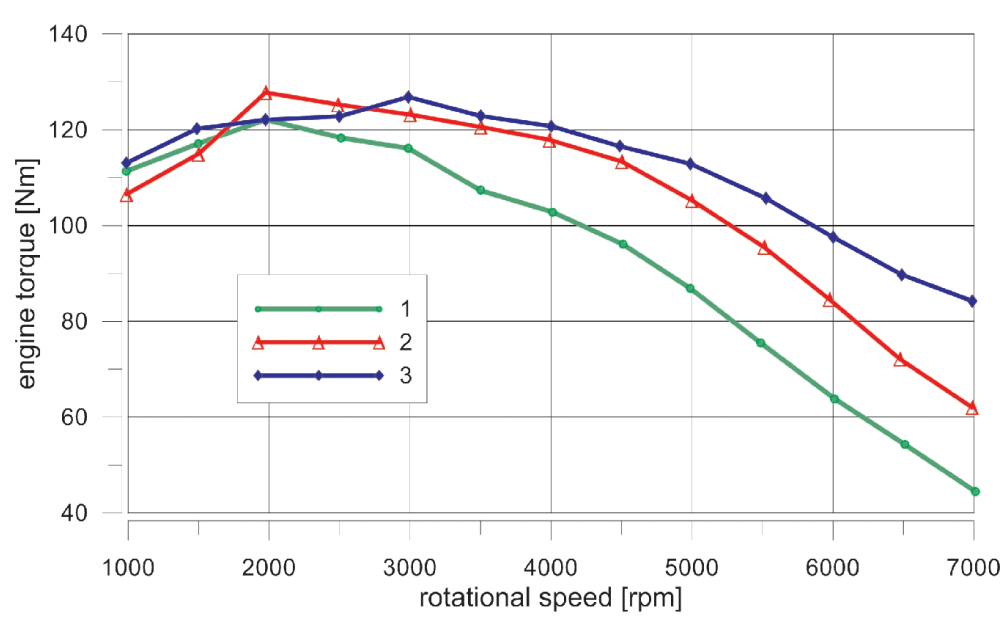

Fig. 12. The calculated engine torque for different types of valve drive systems: 1 - valve driven by a camshaft, 2 - intake valves with a hydraulic drive, 3 - intake and exhaust valves driven by a hydraulic system

Rys. 12. Obliczony moment silnika dla różnych układów rozrzadu: 1 -zawory napędzane krzywka, 2-zawory dolotowe napędzane hydraulicznie, 3 -zawory dolotowe $i$ wylotowe napędzane hydraulicznie

the whole time of its opening a much more air fuel mixture can be delivered to the cylinder. Then the volumetric ratio coefficient could be higher than for the engine with a conventional camshaft. The calculations were carried out for a full throttle at the engine speed in the range from 1000 to $7000 \mathrm{rpm}$. The engine power increases significantly at higher engine speeds in comparison with the power of the engine equipped with valves driven by cams. Figure 11 shows the courses of the effective power for the three cases. The highest increment of power takes place for the engine with both valves controlled by a hydraulic system. At lower engine speeds the increment of power is very small. The variation of torque is close to the torques of compression ignition engines when the hydraulic drive is applied for both valves. In this case we gain a flat torque characteristics as has been shown in Fig. 12 .

Higher engine power of gasoline engines can be obtained through a higher amount of the air or air fuel mixture in the cylinder after the intake valve closes. The engine with valves controlled by a hydraulic system yields higher volumetric efficiency than the standard engine with valves driven by a camshaft (Fig. 13). For the three cases the volumetric efficiency is the highest at lower engine speeds and decreases with the increase of the engine speed.

Because of its high power the engine with a hydraulic valve system consumes much more fuel, which is seen in Fig. 14 that presented the hourly fuel consumption for the three cases. At higher engine speeds this fuel consumption does not increase rapidly but stabilizes on a given level. However, for standard version the engine consumes almost four kilograms of fuel per hour, which is less than the engine of the valve system in version 3 . przebiegi mocy efektywnej dla wszystkich trzech przypadków. Największy wzrost mocy osiągany jest dla przypadku, gdy zarówno zawory dolotowe, jak i wylotowe są kontrolowane przez hydrauliczny system. Dla małych prędkości obrotowych wzrost mocy jest niewielki. Charakterystyka momentu obrotowego przypomina charakterystykę silnika o zapłonie samoczynnym dla przypadku, gdy zarówno zawory dolotowe, jak i wylotowe są sterowane hydraulicznie. Wtedy otrzymuje się płaską charakterystykę momentu obrotowego, pokazaną na rys. 12.

Większą moc silnika ZI można uzyskać dzięki zwiększeniu ilości powietrza lub mieszanki paliwowo-powietrznej. Silnik z zaworami sterowanymi hydraulicznie uzyskuje większy współczynnik objętościowego napełnienia cylindra niż ten sam silnik z zaworami sterowanymi przez krzywki (rys. 13). Dla wszystkich trzech przypadków współczynnik ten jest największy przy małych prędkościach obrotowych, a spada przy wysokich prędkościach obrotowych.

W wyniku uzyskania większej mocy silnik z hydraulicznym systemem napędu zaworów wykazuje również większe zapotrzebowanie paliwa, co pokazano na rys. 14 obrazujacym godzinowe zużycie paliwa dla trzech przypadków. Przy większych prędkościach obrotowych to zużycie paliwa nie wzrasta tak gwałtownie, raczej ustala się na tym samym poziomie. Jednakże przy pełnym otwarciu przepustnicy silnik ze standardowym układem zaworów zużywa prawie $4 \mathrm{~kg}$ paliwa na godzinę mniej niż silnik z hydraulicznym systemem napędu zaworów.

Przy tym samym współczynniku nadmiaru powietrza dla wszystkich analizowanych przypadków jednostkowe zużycie paliwa przy małych i średnich prędkościach obro-

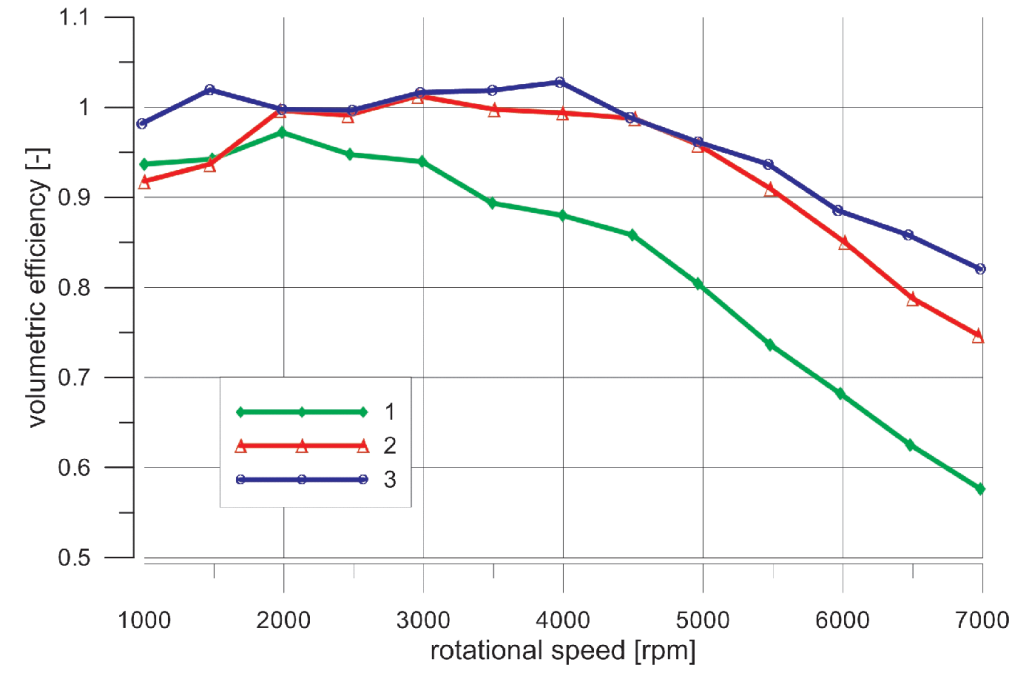

Fig. 13. The calculated volumetric efficiency for different types of valve drive systems: 1 - valve driven by a camshaft, 2 - intake valves with a hydraulic drive,

3 - intake and exhaust valves driven by a hydraulic system

Rys. 13. Obliczony wspótczynnik objętościowego napetnienia cylindra dla różnych układów rozrządu: 1 -zawory napędzane krzywka, 2 -zawory dolotowe napędzane hydraulicznie, 3 -zawory dolotowe $i$ wylotowe napędzane hydraulicznie 


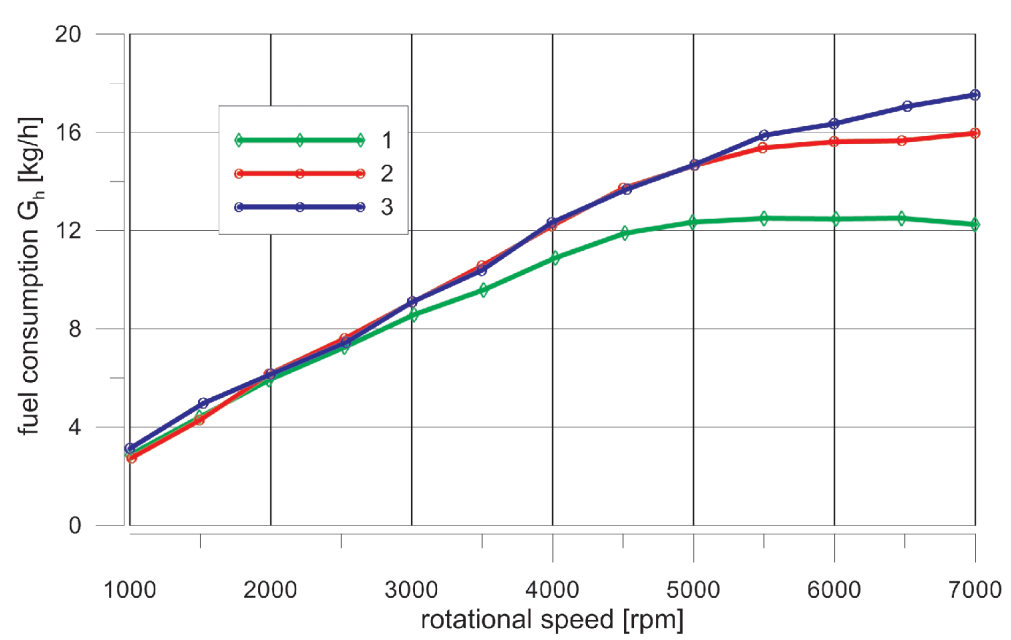

Fig. 14. The calculated hourly mass fuel consumption for different types of valve drive systems: 1 - valve driven by a camshaft, 2 - intake valves with a hydraulic drive,

3 - intake and exhaust valves driven by a hydraulic system

Rys. 14. Obliczone godzinowe zużycie paliwa dla różnych układów rozrzadu:

1 -zawory napędzane krzywka, 2 - zawory dolotowe napędzane hydraulicznie, 3 - zawory dolotowe $i$ wylotowe napędzane hydraulicznie towych pozostaje na tym samym poziomie. Przy większych prędkościach obrotowych odnotowuje się zmniejszenie tego parametru dla hydraulicznego systemu sterowania zaworów, co pokazano na rys. 15 .

Większa moc silnika wiąże się z większym maksymalnym ciśnieniem i temperaturą wewnątrz cylindra. Zmiana czasoprzekroju zaworu przy zastosowaniu hydraulicznego napędu ma wpływ na nieustalony przepływ gazu w kanałach dolotowych i wylotowych, który powoduje zmianę przebiegu fal ciśnienia $\mathrm{w}$ porównaniu $\mathrm{z}$ konwencjonalnym układem rozrządu. Wyniki obliczeń pokazują dużą przewagę hydraulicznego układu rozrządu przy wyższych prędkościach obrotowych.

\section{Wnioski}

$\mathrm{W}$ artykule przedstawiono koncepcję układu rozrządu silnika spalinowego napędzanego hydraulicznie, wstępny model komputerowy symulujący działanie urządzenia przy różnych

For the same air-fuel ratio in the analyzed cases, the course of the specific fuel consumption is on the same level at low and mid range of the engine speed, however, at higher engine speeds the engine with a hydraulic valve system has a lower specific fuel consumption as presented in Fig. 15.

High engine power is also connected with a higher maximum pressure and temperature during the combustion process. The Change of the valve time-area by applying a hydraulically actuated valve train influences the unstable gas flow in the intake and exhaust ducts, which causes a change of the pressure waves in comparison with a conventional valve timing system. The results of the calculations show a great superiority of the hydraulic valve timing system at higher engine speeds.

\section{Conclusions}

The paper presents authors' own concept of a timing system driven by a hydraulic unit, a preliminary computer model for the simulation of the

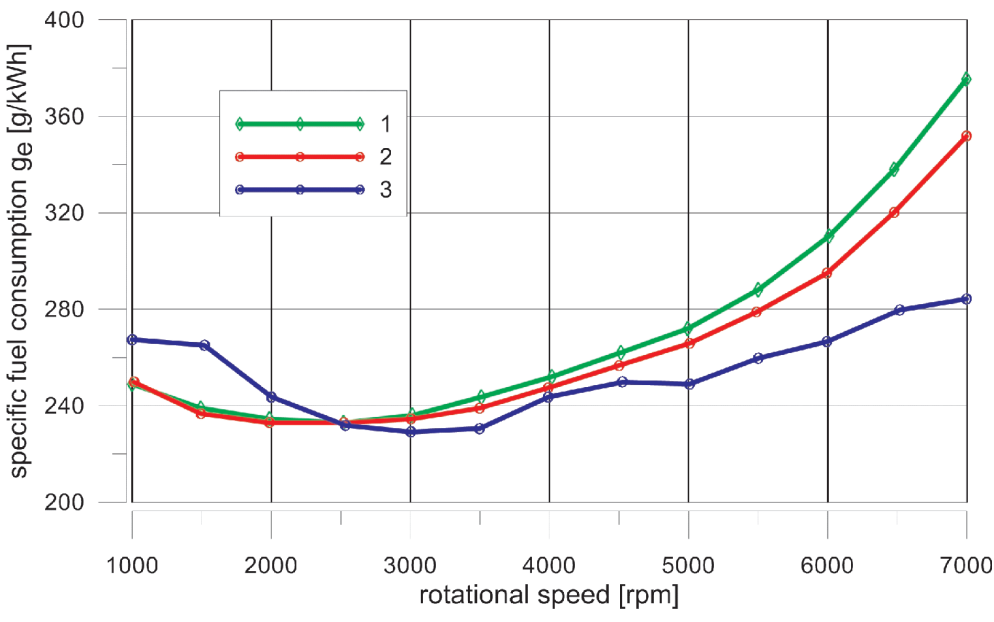

Fig. 15. The calculated specific fuel consumption for different types of valve drive systems: 1 - valve driven by a camshaft, 2 - intake valves with a hydraulic drive, 3 - intake and exhaust valves driven by a hydraulic system

Rys. 15. Obliczone jednostkowe zużycie paliwa dla różnych układów rozrządu: 1 -zawory napędzane krzywka, 2 - zawory dolotowe napędzane hydraulicznie, 3 -zawory dolotowe $i$ wylotowe napędzane hydraulicznie behavior under different operating conditions and to a limited extent comparison of the main operating parameters of the engine with three types of timing system. The preliminary design analysis and results of the computer simulation leads to the following conclusions:

1. Spark ignition combustion engines with a camless unit drive show better work parameters than the engines with conventional cam system.

2. Better characteristics of the valve lift in a function of time results in a higher valve time-area and a higher volumetric efficiency.

3. Hydraulic valve drive system enables the control of the valve lift and decreases valve acceleration in comparison to the cam system.

parametrach pracy oraz częściowo porównano główne parametry pracy silnika spalinowego z trzema układami rozrządu. Wstępna analiza projektu i rezultatów symulacji prowadzą do następujących wniosków:

1. Silnik spalinowy o zapłonie iskrowym z bezkrzywkowym układem rozrządu wykazuje lepsze parametry niż silnik z konwencjonalnym układem rozrządu.

2. Bardziej optymalna charakterystyka wzniosu zaworu wpływa na wzrost czasoprzekroju zaworu oraz na większy współczynnik objętościowego napełnienia cylindra.

3. Hydrauliczny układ napędu zaworów pozwala kształtować charakterystykę wzniosu zaworu oraz zmniejszyć przyspieszenia zaworu w porównaniu do układu krzywkowego. 
4. Feeding pressure of the liquid in the system and readjusting time have the most significant influence on the course of the valve lift.

5. A valve timing system with a hydraulic drive is more complex and more expensive than the conventional system, however, is encouraging for further experimental work and theoretical analysis.

6. Valve forced deceleration is required when it is about to settle in the valve seat, because high liquid pressure results in a substantial impact of one part on the other.

This work has partially been carried out within the Master's Thesis of G. Bac under the promoter of W. Mitianiec in Cracow University of Technology.

\section{Paper reviewed}

4. Ciśnienie robocze czynnika w układzie oraz czas przesterowania rozdzielacza najbardziej wpływają na wznios zaworu w przedstawionym systemie hydraulicznego napędu zaworów.

5. System hydraulicznie napędzanego rozrządu jest bardziej skomplikowany oraz bardziej kosztowny od konwencjonalnego układu rozrządu, jednak wyniki badań zachęcają do dalszych teoretycznych analiz oraz prac eksperymentalnych.

6. Wymagane jest hamowanie zaworu podczas osiadania w gnieździe, ponieważ duże ciśnienie cieczy roboczej powoduje gwałtowne zderzenie się tych dwóch części.

Prace były częściowo przeprowadzone na Politechnice Krakowskiej w ramach pracy magisterskiej G. Baca, której promotorem byt W. Mitianiec.

\section{Nomenclature/Skróty i oznaczenia}

VTEC variable timing electronic control/ elektronicznie sterowany zmienny rozrzad

VVTL variable valve timing and lift/zmienne fazy rozrzadu i wzniosu zaworu
EMV Electro-Mechanical Valve/zawór elektromechaniczny

SI Spark Ignition/zapłon iskrowy

CA Crank Angle/kąt obrotu watu korbowego

\section{Bibliography/Literatura}

[1] Ahrendt W., Savant C.: Serwomechanizmy w ujęciu praktycznym. WNT, Warszawa 1964.

[2] Braden J.S.: Development of a Piezoelectric Controlled Hydraulic Actuator for a Camless Engine. Master Thesis, University of South Carolina, 2001.

[3] Dindorf R.: Wybrane zagadnienia modelowania dynamiki układów hydraulicznych. Wydawnictwo Politechniki Krakowskiej, Kraków 1995.

[4] Hoyer U., Rahnavardi P.: Untersuchung mit Ventilen aus Leichtbau-Werkstoffen. Motortechnische Zeitschrift, Nr.9, 1999.

[5] Hyeong-Joon A., Sang-Yong K., Jee-Uk C., Dong-Chul H.: A New EMV System using a PM/EM Hybrid Actuator. Proceedings of the 2005 IEEE/ASME International Conference on Advanced Intelligent Mechatronics. Monterey, California, USA, 24-28 July, 2005.

[6] Jelali M., Kroll A.: Hydraulic servo-systems: modelling, identification and control. Springer-Verlag, London 2003.

[7] Mrozek B., Mrozek Z.: Matlab 5.x, Simulink 2.x: poradnik użytkownika. WPLJ, Warszawa 1998.

Wladyslaw Mitianiec, DSc., DEng. - Associate Professor in the Faculty of Mechanical Engineering at Cracow University of Technology.

Dr hab. inż. Władysław Mitianiec - adiunkt na Wydziale Mechanicznym Politechniki Krakowskiej. e-mail:wmitanie@usk.pk.edu.pl
[8] Osborn R., Stokes J., Ceccarini D.: The 2/4SIGHT Project Development of a Multi-Cylinder. JSAE Annual Congress, No. 384-20085400, Yokohama 2008.

[9] Pizoń A.: Projektowanie hydraulicznych i elektrohydraulicznych układów automatycznego sterowania. Wydawnictwo Politechniki Krakowskiej, Kraków 1983.

[10] Rychter T., Teodorczyk A.: Teoria silników tłokowych. WKiE, Warszawa 2006.

[11] Wołkow J., Dindorf R.: Metody graficzne w analizie i syntezie układów hydraulicznych. Wydawnictwo Politechniki Krakowskiej, Kraków 1989.

[12] Zbierski K., Smoczyński M.: Motion properties of hydraulically actuated valve train. Journal of KONES Powertrain and Transport, Vol. 16, No. 3, 2009.

[13] Zbierski K.: Koncepcja i bezsilnikowe badania bezkrzywkowego elektrohydraulicznego rozrządu tłokowego silnika spalinowego, Journal of Kones Powertrain and Transport, Vol. 13, No. 3, Warszawa 2006.

Grzegorz Bac, MSc., Eng. - Former student of Faculty of Mechanical Engineering at Cracow University of Technology.

Mgr inż. Grzegorz Bac-absolwent Wydziału Mechanicznego Politechniki Krakowskiej. 